\title{
Igala Proverbs as Bastions of Societal Harmony
}

\author{
Egbunu, Fidelis Eleojo (PhD) \\ Department of Philosophy and Religious Studies, Kogi \\ State University, Anyigba, Kogi State, Nigeria \\ Email: fridele@yahoo.com
}

\section{Doi:10.5901/jesr.2014.v4n6p259}

\begin{abstract}
This paper "Igala Proverbs as Bastions of Societal Harmony" is fundamentally a brisk quest into this all-interesting and allimportant genre of communication among the Igala people of eastern Kogi State of Nigeria. This language group, like many of its counterparts in Africa has many of their moral, social, spiritual and sundry values embedded within these proverbs. Our principal task in this paper is to attempt searching into the deeper signification of such proverbs by means of dialectical and phenomenological methods of investigation. This would enable us educate our audience on the riches of the lgala culture, with the overarching aim of not only keeping records on such value-laden aspects of our culture for the sake of posterity but also focusing on the different dimensions of the usage of proverbs for societal harmony.
\end{abstract}

Keywords: Igala, Proverbs, Bastions, Societal Harmony

\section{Introduction}

The impact of proverbs on the life of people generally within the African setting cannot be overemphasized. This form of communication in the traditional society carries with it some enormous advantage. In what follows, we have a modest attempt to journey through a few proverbs within the Igala environment. This language group is found on the eastern flank of Kogi State of Nigeria. And they are highly esteemed among fellow Nigerians as a culturally oriented set of people. Proverbs form a most central genre of communication in this particular cultural milieu. They are means of forging harmony in various aspects of life. This is especially true as it relates to the sacredness of life and its preservation, respect for the elderly, communal cooperation, solidarity, etc. In what follows, therefore, we desire to give, first and foremost, a working definition of our subject matter, then we shall locate the place of proverbs in the peoples lives before we go through the various contours of sampled proverbs, especially as they relate to the art of human harmonious living.

\section{Proverbs Defined}

Proverbs (ita) are basically, short, popular expressions that give practical admonitions on life. They may come in the form of adages, idiomatic expressions, aphorisms and are generally shortened forms of known myths (ohiala), legends, folktales, etc. in any particular cultural group. Ehusani describes proverbs as "store house and medium of transmission of accumulated wisdom from one generation to the next" (153). In other words, they are short articulations of folk-wisdom, a compact presentation on God, the universe, humans, relationships, destiny and life in general, aimed at instructing, motivating or inspiring people from one generation to the other. They are some sort of condensed philosophical truths which have gone through the test of time. Oduyoye defines proverbs as "short, popular often used sentences that use plain language to express some practical truth that results from experience or observation" (55).

\section{Roles/Usage of Proverbs}

Several proverbs started as ordinary stories in which the proverbs themselves were often the essence or the moral (Kremeneiel 149). Some of them are prescriptive while others are evaluative in outlook. And "through their normative force, serve as a rule of life in the society, giving directives to both young and old" (Madu 196). And for Pogweni, they "are learned, pithy expressions of the wisdom and knowledge of elders" (3). They mirror societal values and articulate cherished virtues. They possess the advantage of being "dynamic and malleable" (Oduyoye 20). We may refer to them as the memory bank or fountain of wisdom and to a certain degree, a measure or yardstick of the people's wisdom. 
Chidili was right when he stated that it has to do with the people's collective memory, "the authoritative source for decision-making, mirror of life from which societal ethics is gauged or couched" (169). The Igbo ethnic group, for instance, term proverbs "the oil with which words are eaten" (Mbaegbu 24, Osuji 137, Ehusani 154, Okoro 340). Some see proverbs as salt which enhances the flavor of food (Orji iv). Yet others call them the kernel which contains the wisdom of the traditional society. The Yoruba, on the other hand, see it as the horse of the word. In this sense, when truth gets lost, people ride towards it through the vehicle of proverbs. It is also considered by some other Africans as the walking-stick for the aged. For the Igala people, proverbs are considered the soup for swallowing yam-fufu and the water that naturally goes with medicine (for the Igala, ita ch'omi kima biogwu). And any adage that does not apply to human life is not true to its name. As they would put it ita noma ofẹn (proverbs are not associated with royalty). Again, eju ki li ta akpita $i$ (it is from constant observation and experiences proverbs emanate). This, to a certain extent, explains why elders are considered as repositories or custodians of wisdom. Elders are seen as mobile encyclopedias. Apart from the moonlight fora, occasions for learning proverbs include different ceremonies such as naming ceremonies, puberty rites, marriage ceremonies, funerals, festivals, settlement of cases, etc. Proverbs are particularly "pivotal in the formation of human person" (Chidili 173). They could be sourced from daily events of life which are often spiced with wise-sayings in a typical traditional environment. Often enough, proverbs are usually suffused with exhortatory, motivational, educative, philosophical, imprecatory and downright spiritually loaded points. As Owan opined, "In one fell swoop, the African proverb can educate, entertain and inform. It can warn, advise, encourage, direct and facilitate one's social and spiritual journey through the twists and turns of life" (xii). Okere's view on this issue is very illuminating, "they are very relevant to any effort to build up a philosophy... and rank already as sayings of wisdom. They are aphorisms evincing a sure knowledge of men and the world" (467). This literary genre is highly loaded with wisdom borne mainly either out of the common experience of the people or the experience of the individuals concerned. Consequent upon their different contexts, they are "capable of multiple base meanings" (Madu 194) perhaps, due to the use of metaphor. Therefore its symbolism or signification cannot be solid or fixed. Rather, "they are semantically indefinite" (Madu 198). That is, they are loose and indeterminate.

For our purposes in this enquiry, a deliberate, if arbitrary choice is made of proverbs which have bearing on human life. In the spirit of hermeneutics of tradition, their interpretations need not necessarily be so literal. Their interpretation could depend on their context or symbolic meanings. In another sense, the hermeneutic paradigm may take any of the methods prescribed by Madu (198), thus: While some are purely semantical and context-free, others could be pragmosemantical or context-based. However, others are syntacto-semantical and therefore in need of expert interpretations (Madu 198). Suffice it to have a cursory look at some examples as the Igala proverb has it, one ma gbeju kẹrẹ b'ọan ya gbeju kere b'ita (if a child never grew up to meet the father, he/she would meet proverbs) in which case, proverbs exist in order to make those who care to be edified by their fount of wisdom.

\section{Igala Proverbs and Their Connotations or Denotations}

The human person in Igala thought has no equal among the animate and inanimate objects in creation. Therefore, both in status and value Ma d'one nw'unefu omin - One does not use the human being to measure the depth of a river; in which case, the use of human persons for ritual purposes or even the scientific usage of human beings for scientific experiments is seen as not only condemnable but highly abominable, since human life is seen as sacred. It is also said, Abudu kone nya ya li ojale - No matter how short a person is, he/she too can see the sky. In other words, nobody is to be despised, even a pauper today may turn out to be the future messiah of the society. In other words, Eneke kaluka eyọ kidefu ẹhia, ama ẹneke kaluka ẹhia monu kidefu eyọ wn - You can count the seed in an apple but you can't count the apple in a seed. Again, Abudu konẹ k'oge ki jẹnn kpai ukọdẹ irida tonẹ gbege $n$ - Teach a monkey how to eat with a fork and spoon, it will never turn into a human person. There is something innate in man which can never be found in all lower animals and even other higher vertebrates, no matter how relatively sensible or sensitive they may seem. $\mathrm{Ma}$ dala w'anyan - There exist no just parameters for comparing the sheep to a horse (especially in running). Or rather, as it is also wittily put, a lizard cannot be a snake. The human person remains the center of focus in the universe, no matter how elegant other creatures might turn out to be.

In relation to the criteria for degree of personhood in Igala thought, it is stated Ichalu kone gbogba chumọlan/ugbejun - Height does not necessarily symbolize growth in a person. Thus, in identifying a person, you do not rate an individual by his or her physical appearance. In other words, do not judge a book by its cover. That explains why it is often said Ẹfonẹ li ibema - Not all that glitters is gold. Ẹnẹ kpa kaa chojoji w'ẹne gamaa - The bigness of a person does not imply his genuineness. 
No amount of material riches or wealth is of greater value than the possession of human persons. Anone tanokole - wealthiness in human resources is greater than material wealthiness. It is also in this light it is said Omanyo tọkole The child is greater than money. Omachoko - The child is greater than all treasures. Agwalo ki ma gwoma - No smith can fashion a child; One nyo tọkole - the human person is greater than money; wealth is therefore considered ephemeral in relation to the facticity of human existence. And so the rhetorical question, Odo monu one aje ile kiagotajiya ebije? - How long will one last in this world that he would order for an iron hat? becomes very crucial. Put differently, One ch'oje kiama ile $n$ - Nobody is like food that lasts through all ages.

In stressing the need for a focused and result-oriented life, it is said Alu kone de ewn nwu ade - The way you make your bed is how you lie on it. Or rather, Alu kone d'oji wn te mala wn - It is the way you place your head that it would be barbed. There is therefore every need for self-restraint; Abia gbei ela imudela ode - If the dog does not control its appetite for meat, it would become a fulltime hunter.

In the up-bringing of children, it is often believed that Ekpe manyọn omanwu anyọn - Like father like son. In another sense, it is mostly by their roots they are known, not necessarily by their fruits. It is often stressed therefore that it is better to train children by showing them good example. As it were, example is better than precepts. The general rule in this case seems to say Ichone katete anoman - It is not only an individual who rears a child; Iko koma defu ichei iye, iye fubi imudeyi oja - A child in the womb belongs to the mother, after birth, it belongs to the entire society. However, no matter what the influence of the society is, Oro agba tonu oko len - The Okro shrub does not grow taller than the person who planted it. It is in this vein therefore that it is believed, Ma keja egben - A fish is better straightened when it is tender and flexible. A stitch in time saves nine. Alternatively, spare the rod and spoil the child. This is of great significance because invariably, Omebune kia nya daiko Imọto ma mọkwo -Morning shows the day.

Children are often cautioned to be obedient to their parents because there are enormous evil repercussions on the stubborn person. Oma ki ma gbọlan efura ya nya filagba - A child who does not listen grows beards only in the grave. In other words, Oma kiẹni iyenwu alolu odun onugonwu alẹn - The child who says its mother would never sleep throughout the night, must also stay awake. On the other hand, great rewards await those who are humble and obedient. Imọtọ kifowọ wn gwẹ nyọnyo ajẹwn kpai ibogujo - A child who washes his hands clean could eat with elders.

People are admonished to be patient and enduring. As such, they are told, Ewn kidabai kima gbegbe edabai Even the biggest fowl that crows the loudest was once a common egg; every fat chicken has its beginning in an egg. In other words, Opepe onwu omi ale yako ocha - little drops of water make the ocean; Rome was not built in a day; the journey of a thousand miles begins with a single step. Agbailo akwane erere achule ulen - You must first learn to walk before you run. And in relation to children and wards, people are cautioned not to throw the baby with the bath-water, thus, Owo we biẹne edu wẹe mu ne fanan - A child is an axe, it may hurt you but you still carry it on your shoulder; the horns can never be too heavy for the cow that must bear them; you don't disown your mouth because it smells. And on another note, Ichalu kuma chọka nyagba chelin - it is not how much but how well. Egbei alu kejo jiji ke kuna nyu efugwujo - If the fire for roasting a snake is prepared according to its length, the house may catch fire; you do not scratch your eyes blind because they itch; a tree does not kill itself because one of its branches is cut-off.

On the need to educate the younger generation adequately or for passing on good skills to youngsters, it is stated, Omekpe kikoji iye ekpe - Success without a successor is failure; Uchu ki nugbe ulu nwu atakpan - A yam with seedlings never goes into extinction; Agaji leku inẹe ahitẹn - When a barren woman dies, she lacks the person to see her off. Therefore, it is submitted that it is better to yield good fruits in season and out of season.

To a typical Igala, character defines a person. Ali maka ma kunyọ - It is character that matters, not beauty. People may behold and admire beauty, but it is seen as something temporal and deceptive. But Ali dabu efu enyo, ali numajan - A person's character is like pregnancy, it cannot be hidden for too long; Ali nyo gbe - ẹchenyo ẹche wọlawe, ẹchebiẹne e echewọlawe - Character is a god, it supports you according to your behavior. And good character entails giving helping hands to neighbours, knowing one's capacity and having the readiness to take on responsibilities accordingly. Iko ke gbei onẹ eggei ọlawe - One good turn deserves another; Ẹnẹ ki bulẹjo ale-i - whom the cap fits, wears it; Ene ki atene ewn kitane ki tẹkpe - whoever wants what is on the ground must bend. Uchu ki nibe akọlawn moli - Good nature is never hidden. More so, it embraces knowledge. And such valuable knowledge is garnered through what looks like Socratic questioning, Atene alan - He who makes enquiries hardly goes astray; Enemali - one mali matene amuna - with others around, confusions are remedied; Emoga dumaja enogwu lenyo - He who hides his sickness hides the medicine man; Amẹ, amọla kọlawn kpai amẹ amọla koja kọ - No matter how intelligent you are, you learn from others. This is because, Udaba aji adeju katen - The riverbank can never be only on one side; there are two sides to a coin. Alewo kia m'okpoje ki teyi atawn le - If you don't move out of your mother's kitchen, you would always think she is the best cook in the world; Ibe takpa efuwe ẹma - The loss of thoughtfulness breeds disaster. On the need 
for indepth observation of reality, the Igala would say, Agobie - Look thoroughly before you leap. They also believe that knowledge is an aid to virtuous living, Amanyi, ene kima ya nyi gen - he who knows the rule should keep it; it is also rendered appropriately as Umoche - Who knows it does it; Egba magba kpa ma mola kpan - Physical maturity does not imply fullness in wisdom.

In life, there is every need to discover or discern one's allotted space: Okpa naka ebina n'adolo; Omere nogba agbere nubi - Everything occupies its divinely assigned space. Yet, one has to be prepared for eventualities, One agwura ya gwutu - You do not put your eggs in one basket. Ogwu kuma juka ajenen - The war that is announced does not consume a cripple; to be forewarned is to be forearmed. The need to strive strenuously in order to make ends meet is seen as a sine qua non for authentic existence. Oli adoji uba anuta elan - No pain, no gain.

The traditional Igala believes anybody can bloom wherever he/she is planted. Therefore, it is necessary to strive through thick and thin. Ugbo du konẹ de yali ochu - Every land has its own sky; Ẹnẹ ki kwu kate onwu aboduu ayọ nwu - It is only the dead person who has everybody on his side; Ukpachi kiteju omi ichọka imeju eche lẹn - A calabash does not need magic to stay afloat; Owailo eni onwu awe le tetete $n$ todu una ki dẹte ajalan - The Chameleon says that he will not alter his dignified manner of walking just because the forest is on fire.

Igala people place strong premium on the need for diligence, mutual support, prudence or reciprocity in love. This also falls under the umbrella of the practice of justice and fair play, both to oneself and others. Takemi olubo ojo ologbo we, foli ka gbe engini-i - If you want to rest under a tree during your old age, plant one now; Abia kigbowo ode mad'ikpala t'ofa - Put a rope round your neck and many people will be happy to drag it; One kpoli una eje kijoru wn Nobody should be deprived of the fruit of his or her labour.

Truthfulness, sincerity, and honesty are virtues which are held in high esteem. In this respect, it is often said, Ajala jegbe kima jili wn - No matter how the harmattan fire burns the grasses, it can never finish its roots; Afu ademi kima dokuta - No matter how the wind blows, it can never lift the stone. In other words, truth is rock-solid and as heavy as the stone, it can never be really tossed off or totally contradicted. Alukaka ma dalukakan alukaka fẹnẹ kpa - Breaking of oath kills. It is as a result of this that whoever is notorious in the community for broken promises or speaking from both sides of the mouth is considered not only unreliable and insincere, but also considered an inconsequential individual.

Igala people believe so much in communal living and the common fatherhood of God. Aje ma rewa one anukwu achukata wa - who eats alone dies alone; Ichẹwn kuwe ẹni omikatete ajoje iye mi ojo kilekwu uwẹkate ki mudu ji when you say that only you would enjoy our mother's food, when she dies, go alone and bury her; Ana du domi komi du duwe own chanade - the right washing the left and the left washing the right harmonious/healthy living; Imoto n'ojimawn ogujo la n'ojima ewn - respect is reciprocal - Onu n'oja koja nonu - the chief owns the subjects as much as the subjects own him; Ikoke gbeyi one egbeyi olawe - Paying attention to other people's predicament shows how you care for yourself; Agwoji kima gweyi ọlawn - no matter how skilful you are you cannot be your own undertaker; Owo imọto agba tojalen, owo ogijo alalu ochan - The hand of the little child cannot reach the upper shelf neither can the hand of the adult pass through the neck of the gourd.There is therefore every need for division of labour. Uwede omidei chonei - A person is a person because of the other people. Nobody is an island; Olikate adago amu d'okon - A tree cannot make a forest; Omaye olawn chodu ebiẹne - Loneliness is a bad name. The need for mutual cooperation is often expressed in many and varied manners: Akpulu ofo neke dagon - An empty sack cannot stand on its own; Chewn ka ma kpiti falu jo ma neke d'adagba -when ants unite, they may even carry an Elephant; Ichẹnn kọwo kpodama ma f'idu ji - when threads join together they tie a Lion; Alu ma chokwujon ya fufon - No whistling is possible without the cooperation of two lips; Alu ma mujọn onẹ meji akpẹrẹn - two people do not walk together unless they are in agreement; Onẹ kate achọla mado ọwoja - One finger soils the others - Ẹne kate a chigọmẹtin - Nobody is an island; Ẹnẹ kate agbeju tọjalen two good heads are better than one; Eli ke kọ kema li enejejen tọno - any song that keeps you solo is not the best; Emi chemi, ewa cheyi oja - Mine is different from ours; it is because snakes live apart from each other that they easily fall prey to men; those who urinate on one spot make it foam. If I help you make it, then I have made it.

Age is highly respected among the people. As such, it is believed that: Ennẹ ki detiba ohimini angọ dito gwejuge $n$ - A man who lives by the riverbank should not wash his hands with spittle. The elders are considered as mobile encyclopedia of wisdom. Therefore the wise person should avail him/herself of this by drinking from their fountain of wisdom. Ewn kogijo dachi ane kili imọto nugọ ẹronu mẹla ili-n - what an elderly person sees while crouching or lying down, a child cannot see even when he stands up or tiptoes nine times over. In other words, the heights attained by great men were not by sudden flights. Aiko chane ekọ magoji wn gẹn - when the cock begins to crow, they do not ask whether it is mature; Ugbo kogijo de anẹ abiẹn

Onẹ anẹe ofe ata akpatogbon - Goats never get caught in a noose when elderly people are around; a she-goat should not suffer the pain of child birth tied to a post while an adult is present. Simply put, to have somebody in the 
rightful position is to be highly privileged.

Children are cautioned against the spirit of stubbornness because it carries devastating repercussions. Aka magbo onwu n'ukwu imoto - A stubborn fly ends up with the corpse in the grave; Ukwu atene kpe if'omu bunye eti That which will kill a man will first block his ears. And for the fear of nemesis, people are cautioned to practice justice, live in peace and harmony with others. Owo ki wura ejo alo - ashes spread towards the direction of the thrower; One who excretes on the road finds flies when he returns; A man who brings home ant-infested faggots should not complain if he is visited by lizards. Ichẹne ku ma jitolu katete alin - as the rain beats the slave, it also beats the slave driver; a person holding his challenger down on the ground is also holding himself down; Ojukpologwu ajuja che k'egbe - the fighter's frontage is full of weeds; the snake that bites the tortoise shall only harm itself; the person who spits at the sky ends up soiling his own face; ashes always come back to those who throw them; the hen that defeacates inside the soup-pot messes up her own grave; you do not use fire to put out fire; one who solves a problem with problem always have problems; if you kill the Cock for dinner, do not expect it to crow next morning; the bush you neglect may produce the rope with which other people will tie you. This is consequent on the fact that living at enmity with others has negative effects. Ene k'idodo agwodaba aji ab'onye inan - He who lives across the river does not make the crocodile his enemy; do not break the bridge that you would cross; when brothers quarrel, their enemy reaps the harvest; when two brothers quarrel, exchange blows and kill themselves, their enemies inherit their homestead and benefits; if you want to burn your house, the enemy will provide you with matches.

The Igala person abhors indolence and so encourages people to avail themselves of every opportunity life offers: Ẹma du tinyọ loji ogban ẹdagbala nyadun - No cross, no crown; Ẹma du wane jẹn ane du nwu we jẹn - Unless the seed dies, no harvest; Ẹma le dufun ẹmọkojẹ ki tei atawa len - travelling is part of education; Ejuka ma kpọfọn ekeji ali omi mọn - you must lose in order to gain; You can not eat your cake and have it.

The need for contentment, taking precaution, avoiding corruption and sundry issues are replete in their proverbs: Ma dẹre one nwadaban - you can not see with another man's eyes; you don't drink medicine on behalf of a sick person; you can share the same bed with a person but not the same dream. Ẹka nwimọtọ kilulẹ odun yẹni ochu afanẹ - when the termite ventures out to fly in the sky like a bird, it becomes food for the hawks; the Calabash can never have a happy relationship with a stone; the mouse cannot be the landlord of a cat; the kite and chick do not go the same market; an egg has no business dancing with stones; you cannot send a cat to take message to a dog; whoever shoots arrows upwards must take care to protect his head; a man who throws stones in a market place should not be surprised if his wife comes home blind on one eye; you cannot fight a fire while wearing a grass skirt; Agwimojẹ odu achọlanwu icheya - mockery done behind does not affect the intended victim; you do not wink at somebody in the dark - lle anwa, ojo aga lona ewn - man contrives but God decrees; Ojo atu ene achi kia lo ẹne okpe - God is the author of fortunes. Corrupt individuals are scorned with passion: Alu fewn je ikpo kejeji - the corrupt person speaks from both sides of the mouth; Alu fẹwn jẹ imugọ - After eating, the mouth bends; Alu jẹ biẹnẹ anyọ feju mu - the mouth that eats badly brings shame to the face.

People's roots are said to have lasting impacts on their lives: Ewn kiajẹnwu egbe chiche chofewu idẹi - the insect that eats the leaf is under the leaf; what makes the leaf dance is under its root; Enyo one chefu obuka iyewn yakwo morning shows the day; Ete ikwu ma fikwu kwo - Charity begins at home. Hospitality is practiced with an overwhelming candour: Ojoru - eju ononojo ma jọme, ubi wn mara - visitors are like the dew, they are around only for a while; Ejumaje takwu majoje - a sour face can render a valuable gift unacceptable.

The virtue embedded in doing things at their rightful times carries great emphasis among the people. Eju gbogbo mamewo dudu tikwu - it is better to start early to look for a black goat because at night a black goat would be difficult to find; Aladi kianyọ ojọ ichate ya nyọ kwo; Odudu ma rule ojọ edu - a stitch in time saves nine; morning shows the day; as you make your bed so you lie on it; Olule ojọdu - sunset announces the end of the day; Egba oli majọn ya bun; Aja akpere akọn - there is time for everything; Ugbo kukwu kpa kade chudọme ogijo - whom death spares carries on the duty of the elders; Ukwu cholu chona ene du megba len - Death is like sleep and dream, no one knows the exact time; Ukwu kpego kailo kibego - the death of an age-mate is a frightful reminder; Ojọmakpenen - if God does not decree your death, you do not die.

There are yet other proverbs that we might classify under sundry issues: Abojo nyẹene own ya dẹi - The way God made one remains his/her nature; u can't fully change nature; Abowa joi chabo $n$ - Everybody's business is nobody's business; Ewn chihianyi oma kidefu iyewn kpai odudu obuka - A child in the womb is never worried about how smoky the mother's kitchen is; Oma kidubi iyewn imalu kujiji ule dẹn - the child who is carried on its mother's back does not know how long the journey really is; Oma chagba - a child is the handcuff, with it, you do not move out at your wish; Udachi iy'ejima ch'ajinga - the mother of twins should have impartial breasts; Abo kit'egwu ubi ajewn negahi-i - it is the 
human followers that constitute the power of the masquerade; Ewn ki ane ule ma min uwe onugo amin - if what is pursuing you has not relented, you cannot afford to slacken your pace; Obe jẹn ako jẹn anihianyi wa - Endless disagreement breeds trouble; Uja obuka anakanya wa; Eju we magbodudun ẹkwo bejuwn te - If you cannot withstand smoke, stay afar off from the chimney; Ekpa mi êkp'odu min - You may kill a man, but you cannot kill his name; Ajoji an'eti akoya, Ola achọla chija ija - Clear conscience fears no accusation; the criminal runs when no one pursues him.

There are yet other forms of figurative expressions with some sort of cultural resonance which are solid metaphors relating to animals or plants. Such imageries carry a lot of connotational meanings when used in Igala culture. A few examples include:

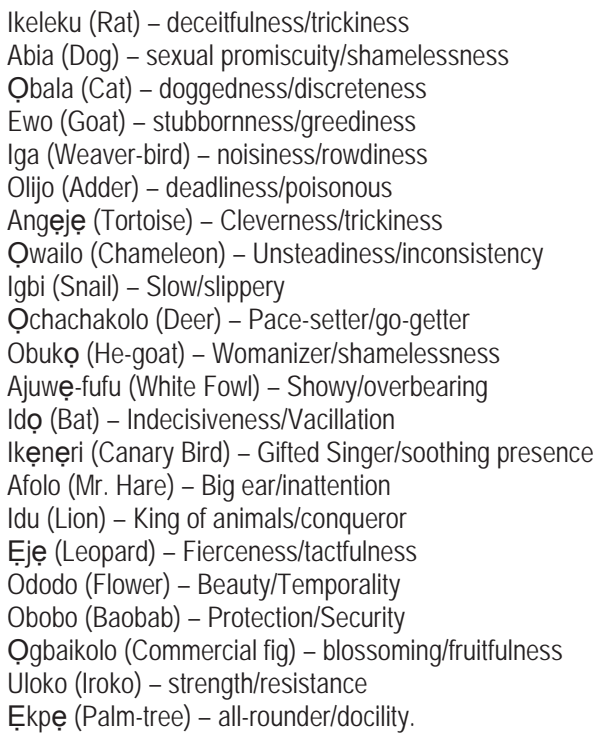

\section{Conclusion}

As can be easily gleaned from the above excursus through this genre, the Igala language group possesses an inexhaustible reservoir of wisdom in their proverbs. These proverbs are not only of much value to the elders whose speeches are most often garnished or embellished with them in their bid to draw home their messages in season and out of season. Proverbs, as it were, also enable them to relay very significant pieces information among their peers without unnecessarily divulging their secret codes to the uninitiates. More so, this has over the ages the advantage of not only edifying their audiences but also making them able to keep some good records of the people's customs and traditions from one generation to the next. By so doing, an enormous deal of harmony, peace and understanding is easily forged among the people. Put differently, to be equipped with them in the Igala, nay African society is akin to possessing enough arrows in ones quiver at the war front.

\section{References}

Chidili, B.U. Pedagogy of Human Dignity: Through the Vision of Mercy Amba Oduyoye. Fab Educational Books: Jos, 2008.

Ehusani, G. (1997). An Afro-Christian Vision "Ozovehe"!. New York: Macmillan.

Kremenlier, B. "Proverbs of the Bulgarian People" in Journal of American Folkore, Vol. 65, No. 255, 1952. Pp. 149-153.

Madu, R.O. Studies in African-American Culture - African Symbols, Proverbs and Myths: The Hermeneutics of Destiny. Peter Lang: New York, 1992. Mbaegbu C.I. "African World-View: Its Ontological Status" in Ogirisi - A New Journal of African studies Vol 2 No.1, 2004, Pp. 1-13.

Oduyoye, M.A. "Be a Woman and Africa will be Strong" in L.M. Russell et al

(Eds.) Inheriting Our Mother's Gardens. The Westminster Press: Philadelphia, 1998, Pp. $22-29$.

Okere, T. African Philosophy: A Historico-Hermeneutical Investigation of the Conditions of its Possibility, University Press of America, Lan han, 1983.

Okoro, N.A. Popular African Proverbs, Vol. 3. San Press: Enugu, 2007.

Orji, E. 1350 Igbo Proverbs, (No publisher and Place), 1984.

Osuji, C. Foundation of Igbo Tradition and Culture. Opinion Research: Owerri, 1998.

Owan, K.J.N. African Proverbial Wisdom Series, Vol. 1. The Ambassador Publications: Iperu-Remo, 2000.

Pongweni, in Ehusani G.O. An Afro-Christian Vision Ozovehe: Towards a More Humanized World. University Press of America: New York, 1991. 